\title{
Age estimation and growth pattern of the island grouper, Mycteroperca fusca (Serranidae) in an island population on the northwest coast of Africa
}

\author{
ROCÍO BUSTOS, ÁNGEL LUQUE and JOSÉ G. PAJUELO
}

Departamento de Biología, Universidad de Las Palmas de Gran Canaria, Campus Universitario de Tafira, Edificio de Ciencias Básicas, 35017 Las Palmas de Gran Canaria, Spain. E-mail: jpajuelo@ dbio.ulpgc.es.

\begin{abstract}
SUMMARY: Mycteroperca fusca is one of the main predators of the Canarian archipelago coastal marine ecosystem. Nothing is known on the life history or population dynamics of this predatory serranid fish. In this study, age and growth of $M$. fusca were investigated by annual growth increment counts from 214 fish collected between January 2004 and December 2005. A year's growth is represented by one opaque and one translucent ring. The island grouper is a slow-growing and long-lived species, with ages up to twenty years recorded. Length at age was described by the von Bertalanffy growth model $\left(\mathrm{L}_{\infty}=898 \mathrm{~mm} ; \mathrm{k}=0.062\right.$ year $^{-1} ;$ and $\mathrm{t}_{0}=-3.83$ year $)$, the Schnute growth model $\left(\mathrm{y}_{1}=262 \mathrm{~mm} ; \mathrm{y}_{2}=707 \mathrm{~mm} ; \mathrm{a}=0.008\right.$; and $\mathrm{b}=1.98)$, and the seasonalised von Bertalanffy growth model $\left(\mathrm{L}_{\infty}=908 \mathrm{~mm} ; \mathrm{k}=0.061\right.$ year $^{-1} ; \mathrm{t}_{0}=-3.83$ year; $\mathrm{C}=2.58$; and $\left.\mathrm{t}_{\mathrm{s}}=0.542\right)$. Males and females show differences in growth.
\end{abstract}

Keywords: Mycteroperca fusca, grouper, age, growth, otoliths.

RESUMEN: ESTIMACIÓN DE LA EDAD y PATRÓN DE CRECIMIENTO DEL ABADE, MYCTEROPERCA FUSCA (SERRANIDAE) EN UNA POBLACIÓN ISLEÑA EN LA COSTA NOROESTE DE ÁFRICA. - Mycteroperca fusca es uno de los principales depredadores de los ecosistemas marinos del Archipiélago Canario, del que nada se conoce sobre su biología. En este trabajo, se aborda el estudio de la edad y el crecimiento de $M$. fusca mediante el recuento de los incrementos anuales de crecimiento a partir de 214 ejemplares recolectados entre enero de 2004 y diciembre de 2005 . El crecimiento anual está representado por un anillo opaco y otro translúcido. El abade es una especie perteneciente a la familia Serranidae de crecimiento lento y de vida larga, con edades registradas superiores a los veinte años. La relación entre la talla y la edad se estimó mediante el modelo de von Bertalanffy $\left(\mathrm{L}_{\infty}=898 \mathrm{~mm} ; \mathrm{k}=0.062 \mathrm{años}^{-1} ; \mathrm{y} \mathrm{t}_{0}=-3.83\right.$ años$)$, el modelo de Schnute $\left(\mathrm{y}_{1}=262 \mathrm{~mm} ; \mathrm{y}_{2}=707 \mathrm{~mm} ; \mathrm{a}=0.008 ; \mathrm{y}\right.$ $\mathrm{b}=1.98)$, y el modelo estacional de von Bertalanffy $\left(\mathrm{L}_{\infty}=908 \mathrm{~mm} ; \mathrm{k}=0.061\right.$ años $^{-1} ; \mathrm{t}_{0}=-3.83$ años; $\left.\mathrm{C}=2.58 ; \mathrm{y} \mathrm{t}_{\mathrm{s}}=0.542\right)$. Los machos y las hembras presentaron diferencias en el crecimiento.

Palabras clave: Mycteroperca fusca, abade, edad, crecimiento, otolitos.

\section{INTRODUCTION}

Fish communities pass through a series of structural changes as they are increasingly heavily fished (Jennings et al., 2001). High trophic level species decrease in abundance, and high trophic level specimens form a smaller proportion of the total abundance and biomass. Ultimately, fish communities are dominated by smaller individuals of a low trophic level and short- lived species (Jennings et al., 2001). This is the result of the intensity of fishing for high trophic level and long-lived fish, a phenomenon now widely known as "fishing down marine food webs" (Pauly et al., 1988). Overexploitation of the fishery resources of the Canary Islands has resulted in the collapse of the population of large predators present in the area, mainly the large species of the Serranidae and Sparidae families (Pajuelo and Lorenzo, 1995; Tuya et al., 2005). 
One of the main serranid species present in the waters of the Canary Islands is the island grouper Mycteroperca fusca (Loewe, 1836). Its population has collapsed, with a depletion of the total landing of this species of approximately $95 \%$ over the last fifty years, due to the heavy pressure of fishing (Tuya et al., 2005; Bustos, 2008). No bag limits are currently imposed on its fishery and only minimum size legislation $(350 \mathrm{~mm})$ has been implemented.

Mycteroperca fusca is a sub-tropical species found in the central-east Atlantic, around the islands of Madeira, the Azores, the Savage Islands, the Canary Islands and Cape Verde (Heemstra and Randall, 1993, 1999). There is no information about the characteristics of its life cycle. This is due to the fact that for many years $M$. fusca were confused with Mycteroperca rubra (Bloch, 1793), until Heemstra (1991) established that the species found in the Macaronesian region in Atlantic waters was $M$. fusca, with the distribution of $M$. rubra being limited to the west coast of Africa and Mediterranean waters (Heemstra and Randall, 1993, 1999).

The lack of biological data of the island grouper is particularly worrying since it is considered that the correct management of biological resources should be grounded in the most complete information about the ecology of the species involved. The aim of this paper is to estimate the age composition, longevity, and growth rate of the population of the island grouper by means of otolith reading, applying some indirect age validation methods to support the accuracy of age estimates. These results may contribute to a better understanding of the ecology of this poorly known species, and can be used to revise the management rules applied to Mycteroperca fusca based on the biological characteristics of M. rubra.

\section{MATERIALS AND METHODS}

A total of 214 individuals of the island grouper were collected from commercial catches taken between January 2004 and December 2005 off Gran Canaria and Fuerteventura (Canary Islands, northwest Africa). Fish were caught with line at depths of 5-150 m.

Each fish was measured to the nearest $\mathrm{mm}$ for total length $(\mathrm{Lt})$ and weighed to the nearest $\mathrm{g}$ for body weight (Wt). All gonads were also fixed and preserved in $4 \%$ buffered formaldehyde and subsequently processed, histologically. Slices of tissue were embedded in paraffin, sectioned at $5 \mu \mathrm{m}$ and stained with Harris haematoxylin followed by eosin counter stain. Sectioned and stained tissue was subsequently examined under a light microscope. The sex was determined from the histological sections. Fish were identified as females, males or in transition from female-to-male following Sadovy and Shapiro (1987) and Brulé et al. (2003a,b).

Sagittal otoliths were removed, cleaned, and stored dry for later age determination. In order to determine the most adequate reading method, whole and frontal sections of otoliths, out of a subsample of 40 specimens of differing sizes between 400 and 720 millimetres, were compared using an age bias plot and a paired $t$-test analysis, and the following three section-based age categories, 11$13,14-16,17+$ years, were estimated by dividing the age range by three (Campana et al., 1995; Campana, 2001). Otoliths were embedded in series in aluminium moulds. They were laid out on a base of black-coloured polyester resin. Frontal sections of $3 \mathrm{~mm}$ otoliths were cut with a high-speed diamond saw. Finally, the sections were polished by hand using wet abrasive paper, following McCurdy et al. (2002). The age was determined by interpreting growth rings on the whole and sectioned otoliths. Annuli were counted from the core to the rostrum on the distal face of the otoliths along the antero-posterior axis (Panfili and Morales-Nin, 2002b; Wright et al., 2002). Each pair of otoliths was observed and subjected to two readings by the same observer using both pieces simultaneously. To avoid subjectivity and to achieve independent interpretations, each of the readings was separated from the other by a space of three weeks, without any details of the fish being known in advance. The data obtained from each of the readings were recorded in independent files, following the nomenclature of the growth rings proposed by MoralesNin (1987) and Morales-Nin and Panfili (2002b). To carry out the readings, a binocular magnifying glass was used (10X). The otoliths were read using light reflected by the concave part on the upper side (distal face). By using this type of illumination, the opaque rings were observed more clearly than the rest of the otolith, and the translucent rings were seen to be darker. Previous to these readings, different liquids, which included sea water, ethanol and glycerol were used to enhance the growth rings. Burning and staining techniques were also used to enhance the growth rings (McCurdy et al., 2002). 
There were no effects of the quality of the preparation technique on the enhancement of the growth ring. Therefore, water was adopted as the standard protocol. It is not recommended that the parts be left submerged in water for a long time since the rings cease to be visible and readings may be erroneous. The marginal increment (distance from the inner margin of the outermost translucent ring and the periphery of each otolith, MI) was measured on whole otoliths.

To determine the periodicity of the growth rings, the proportion of opaque and translucent margins was calculated on a monthly basis (Morales-Nin and Panfili, 2002a). The outer ring was considered to be either opaque or translucent only when the entire edge showed this characteristic. To validate the periodicity in the increment formation at each age class, the marginal increment analysis was estimated (Panfili and Morales-Nin, 2002a). Marginal increment analyses should be standardised for age because younger fish grow faster than older ones. However, age classes above 10 years were poorly represented and the width of the marginal increments was only modelled for individuals aged 10 years and below.

Estimates of ageing precision were determined using two methods: the index of average percentage error (Beamish and Fournier, 1981) and the coefficient of variation (Chang, 1982).

Individual ages were corrected by the birthdate (1 July), corresponding to the mid-point of the spawning period (Bustos, 2008), the main periods of seasonal increment formation and the nature of the otolith edge, and took into account the date of capture (Morales-Nin and Panfili, 2002b). The difference between the date of capture and the birth date helps the reader to estimate the annual fraction elapsed since the last birthdate, and the annual fraction is added to the number of complete hyaline zones read in the otoliths to avoid any potential bias in growth estimates due to the differences in sampling date (Gordoa and Molí, 1997). The Kolmogorov-Smirnov non-parametric $Z$-test was used to analyse the differences in the range of male and female sizes (Sokal and Rohlf, 1995).

Length-at-age was described by the von Bertalanffy growth model (Ricker, 1975),

$$
L_{t}=L_{\infty}\left(1-e^{-k\left(t-t_{0}\right)}\right),
$$

the model of four parameters, according to Schnute (1981),

$$
L_{t}=\left[y_{1}^{b}+\left(y_{2}^{b}-y_{1}^{b}\right)\left(\frac{1-e^{a\left(t-A_{1}\right)}}{1-e^{-a\left(A_{2}-A_{1}\right)}}\right)\right]^{\frac{1}{b}},
$$

and the seasonalised von Bertlanffy growth equation (Pitcher and Macdonald, 1973),

$$
L_{t}=L_{\infty}\left(1-e^{-k\left(t-t_{0}\right)-\left(\frac{C k}{2 \pi} \sin \left(2 \pi\left(t-t_{s}\right)\right)\right)}\right),
$$

where $A_{1}$ is the lowest age in the sample; $A_{2}$ is the highest age in the sample; $t_{0}$ is the age at zero length; $L_{t}$ is the length-at-age $t ; L_{\infty}$ is the predicted asymptotic length; $y$ is the estimated mean length of $A_{1}$ year old fish; $y_{2}$ is the estimated mean length of $A_{2}$ year old fish; $C$ is the amplitude of the fluctuation in seasonal growth; $t_{s}$ is the addition of the point of the minimum growth $(W P)+0.5 ; a$ and $b$ are parameters estimated by the models; and $k$ is the Brody growth constant. A non-linear method of Levenberg-Mardquart's algorithm was used to estimate the growth parameters. Temperature data provided by the satellite reception station, SESAP (Gran Canaria), were used to relate formation of growth rings to sea surface temperature. Hotelling's $T^{2}$ test was used to compare growth parameters between males and females (Bernard, 1981).

\section{RESULTS}

The lowest values of the monthly mean width of the marginal increment were recorded in January-February with an increasing trend throughout the year (Fig. 1). Thus, irrespective of the number of translucent rings in the otoliths, one mode was observed during a 12-month period. Therefore, it was assumed that each translucent ring represented an annulus, with a year's growth represented by an opaque ring and its adjacent translucent one. One growth increment consisting of one opaque and one translucent ring was formed on an annual basis, with the opaque ring being deposited mainly between May and October (Fig. 2). There was no apparent time lag from the start of the increase in seawater temperature and the beginning of formation of the opaque ring. The formation of the translucent rings coincided with the decrease in surface seawater temperature (Fig. 2).

The shape of the sagittal otolith was oblong. Annuli were clearly differentiated under reflected light on a black background with the opaque rings milky in appearance and the translucent rings relatively transparent (Figs. 3, 4). 


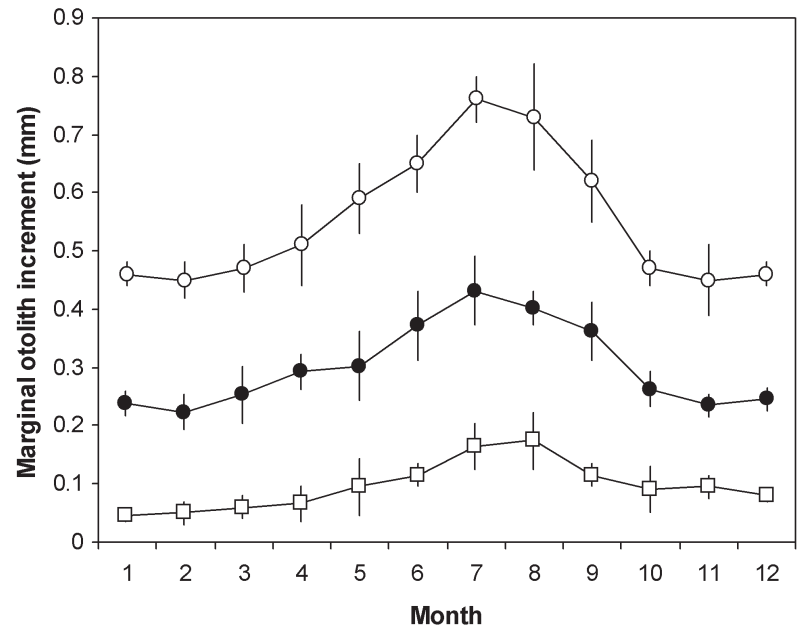

FIG. 1. - Mean monthly width of the marginal increment from otoliths of Mycteroperca fusca for specimens of 2-4 years (circle; $\mathrm{n}=50$ ), $5-7$ years (solid circle; $\mathrm{n}=63$ ), and $7-10$ years (squares; $n=33$ ) off the Canary Islands. Each error bar represents the standard deviation. Age 11+ fish were not used.

Whole otoliths and sectioned counts were compared using a paired $t$-test for the following age categories: 11-13 ( $n=14), 14-16(n=15), 17-20(n=11)$. The values of the matched pair $t$-test revealed that there were no significant differences between the

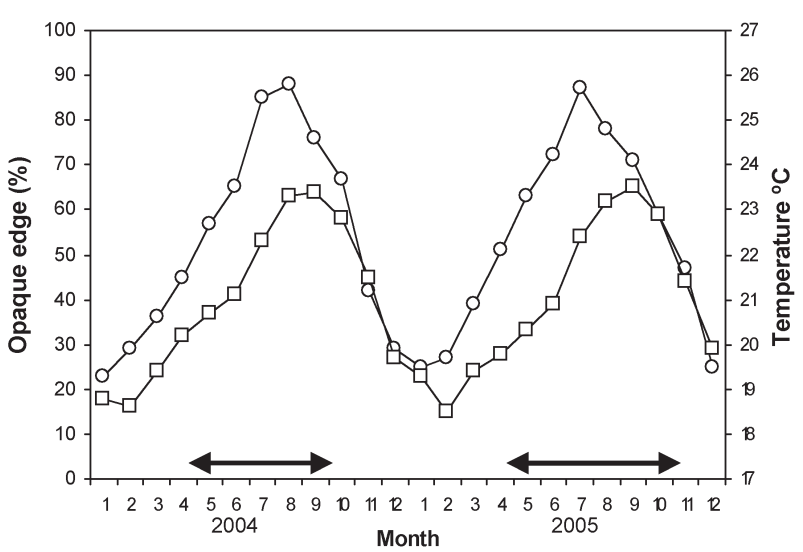

FIG. 2. - Monthly proportion of opaque edge (circle) observed in whole otoliths of Mycteroperca fusca off the Canary Islands, and mean monthly variation of the sea surface temperature (squares). The arrows represent the months of annual opaque ring formation.

ages as determined by whole otoliths or sections across all the age groups section-based $(p>0.01)$. Age bias plots of ages estimated from whole otoliths compared to ages estimated from sections revealed no discrepancy between the two methods (Fig. 5), so the age was estimated from whole otoliths.

Out of 214 otoliths examined, only 26 (12.15\%) were discarded because they were unreadable, bro-

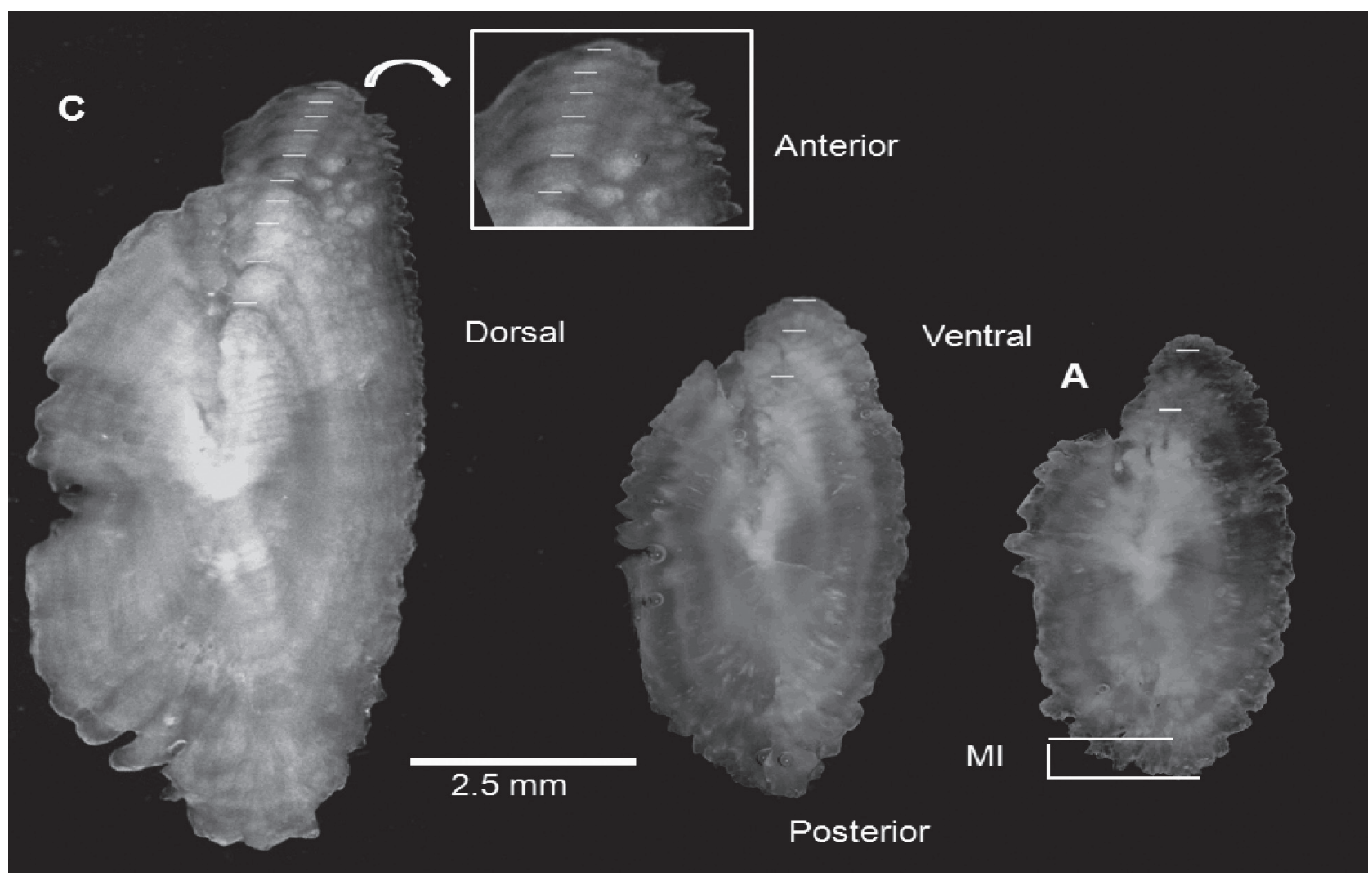

FIG. 3. - Sagittal otoliths of Mycteroperca fusca off the Canary Islands. A, a 2-year-old specimen (272 mm); B, a 3-year-old specimen (317 $\mathrm{mm})$; and C, a 10 -year-old specimen $(521 \mathrm{~mm}) . M I$ is the width of the marginal increment measured. Annuli are represented at the outer margin of the translucent bands. 


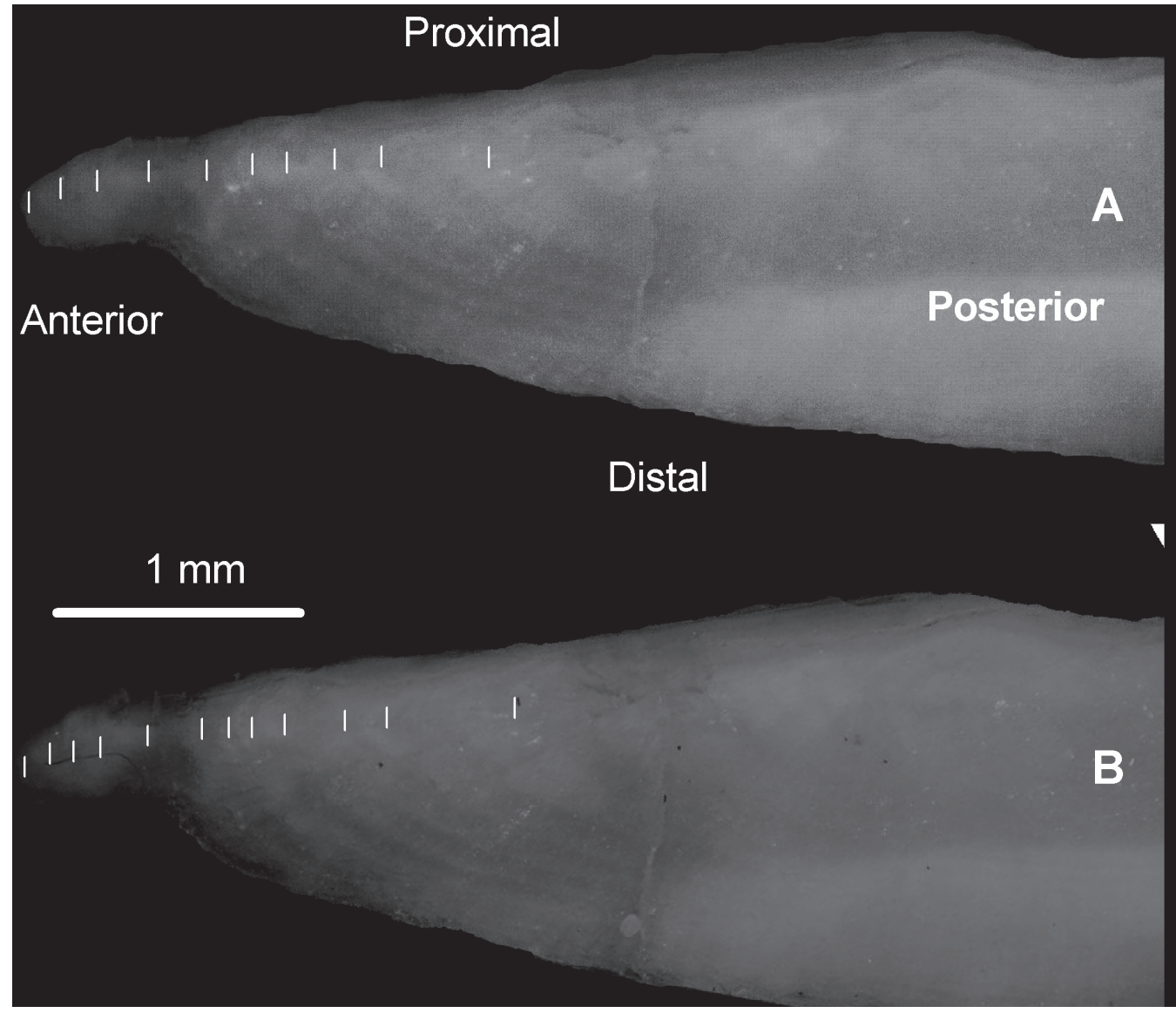

FIG. 4. - Sagittal otoliths of Mycteroperca fusca off the Canary Islands. A, Frontal section oriented in the antero-posterior axis of the otolith of 10-years-old specimen $(521 \mathrm{~mm})$; B, frontal section oriented in the antero-posterior axis of the otolith of 12-year-old specimen (567 mm). Annuli are represented at the outer margin of the translucent bands.

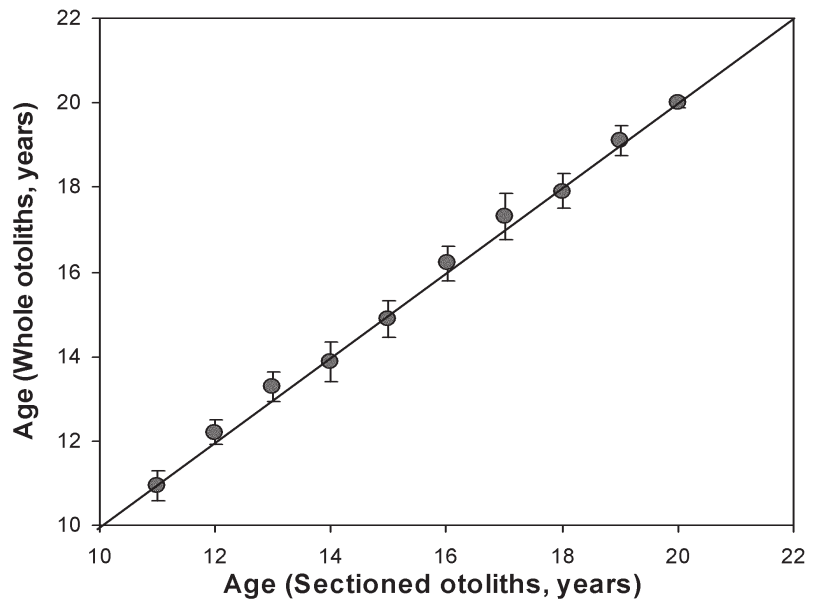

FIG. 5. - Age bias plot for ageing whole otoliths and sectioned otoliths of Mycteroperca fusca. Each error bar represents the standard deviation and circle the mean value. The 1:1 equivalence (solid line) is also indicated.

ken or provided different age estimates across readings. Overall, 35 males between $332 \mathrm{~mm}$ and 720 $\mathrm{mm}$ and 153 females between $229 \mathrm{~mm}$ and $710 \mathrm{~mm}$ were aged. The range of length differed significantly (Kolmogorov-Smirnov non-parametric test, $\mathrm{Z}=5.34$, $p<0.0001)$ between males and females. The values of the index of average percentage error IAPE $=5.1$ and the coefficient of variation $\mathrm{CV}=5.9 \%, \mathrm{p}>0.05$ were both low, indicating the goodness of the ageing procedure adopted and a reasonable level of consistency (or reproducibility) between readings.

Up to twenty marks, assumed to be annuli, were visible in the otoliths sampled. Two- to nine-yearold fish were the dominant age classes and only $22 \%$ of fish were ten years old or older (Table 1). Over $28 \%$ of the growth was achieved by the second year. In the fourth year of life, the fish attained a length approximately half of the maximum length observed. Age estimates ranged between 2 and 20 years for females and 3 and 20 years for males. Significant differences were found between males (10.31 year) and females (7.07 years) in mean age $\left(t\right.$-test, $\left.\mathrm{t}=3.97>\mathrm{t}_{0.05,186}=1.96\right)$.

The three growth models provided a good fit to the data (Fig. 6, Table 2). The computed value of 0.042 for the winter point of the seasonalised von Bertalanffy model indicated that the lowest growth 
TABLE 1. - Age-length key of Mycteroperca fusca off the Canary Islands; $x$ is the mean length; $n$, the number of fish by age class; and sd the standard deviation. Total length classes are in $20 \mathrm{~mm}$ intervals.

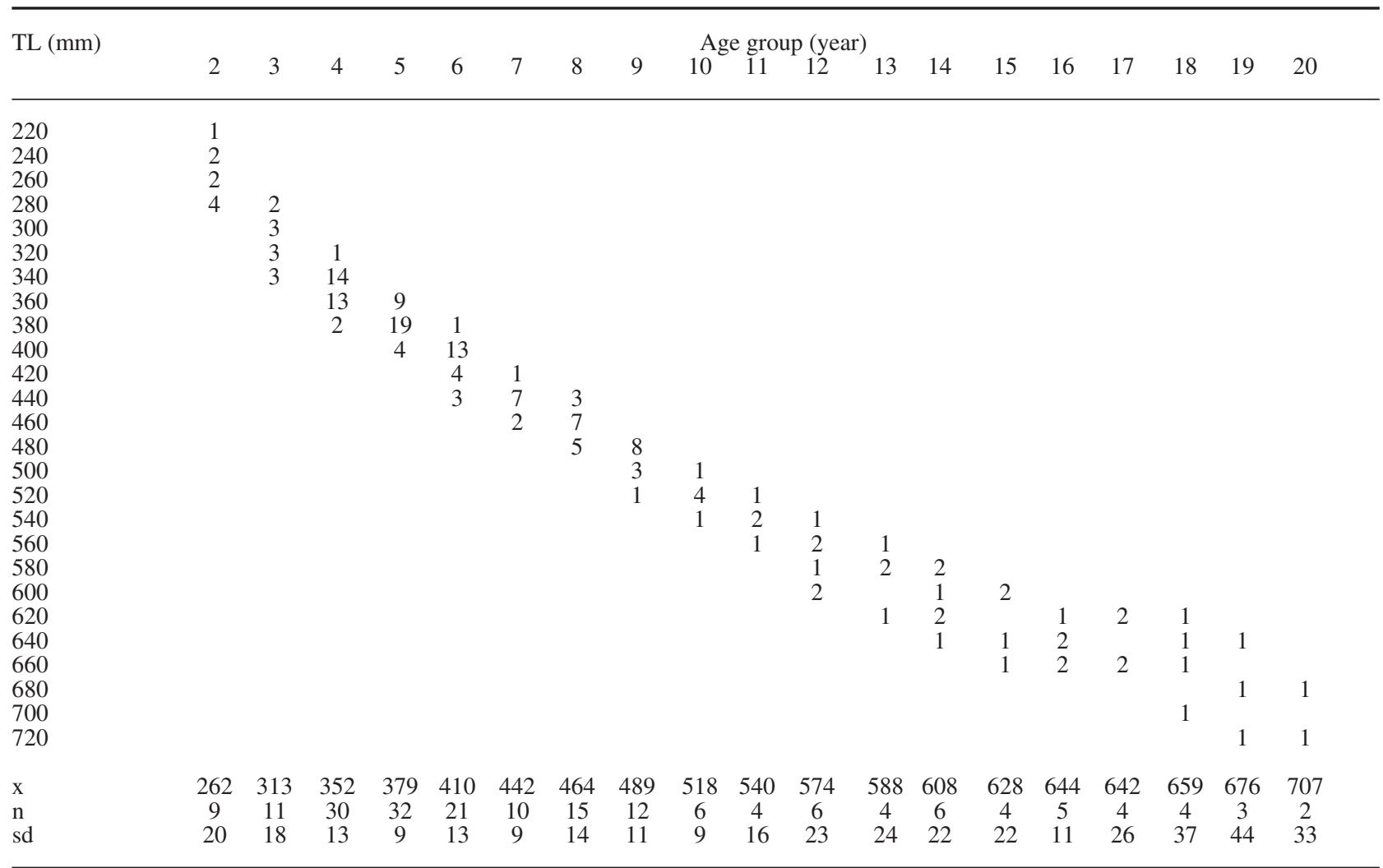

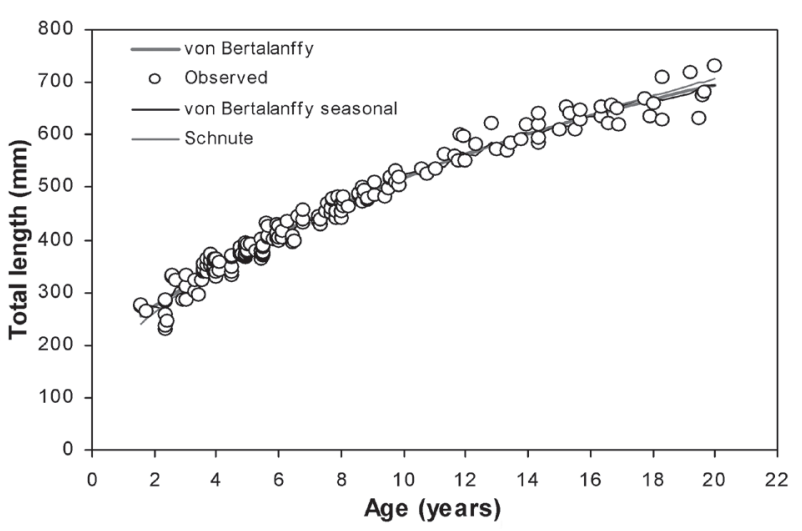

FIG. 6. - Observed total length-at-age and relationship of age to total length predicted from von Bertalanffy growth model, Schnute growth model, and seasonalised von Bertalanffy growth model $(\mathrm{n}=188)$ for Mycteroperca fusca off the Canary Islands.

rate occurs about six months after the date of birth, meaning that the growth is reduced in winter. No significant difference was found between the von Bertalanffy models and the Schnute model (Likelihood ratio test; $\mathrm{F}<\mathrm{F}_{0.05,2,184}$ ). Therefore, the von Bertalanffy growth model was chosen, since the model is more solid from the statistical perspective, describing growth in the simplest way, using fewer parameters, and allowing ease of comparison be-
TABLE 2. - Parameter estimates for the von Bertalanffy growth model (VB), the Schnute growth model (S), and the seasonalised von Bertalanffy growth model (SVB) for all fish of Mycteroperca fusca off the Canary Islands.

\begin{tabular}{lcc}
\hline Parameter & Value & Standart error \\
\hline $\mathrm{VB}\left(\mathrm{r}^{2}=0.976\right)$ & & \\
$\mathrm{L}_{\infty}(\mathrm{mm})$ & 898 & 35.99 \\
$\mathrm{k}($ years & & \\
$\mathrm{t}_{\mathrm{o}}$ (years $)$ & 0.062 & 0.006 \\
$\mathrm{~S}\left(\mathrm{r}^{2}=0.970\right)$ & -3.83 & 0.343 \\
$\mathrm{y}_{1}(\mathrm{~mm})$ & & \\
$\mathrm{y}_{2}(\mathrm{~mm})$ & 262 & \\
$\mathrm{~A}$ & 707 & \\
$\mathrm{~b}$ & 0.008 & 0.017 \\
& 1.98 & 0.311 \\
$\mathrm{SVB}\left(\mathrm{r}^{2}=0.976\right)$ & & \\
$\mathrm{L}_{\infty}(\mathrm{mm})$ & 908 & 34.73 \\
$\mathrm{k}($ years & & 0.005 \\
$\mathrm{t}_{\mathrm{o}}$ (years $)$ & 0.061 & 0.318 \\
$\mathrm{C}$ & -3.83 & 0.439 \\
$\mathrm{t}_{\mathrm{s}}$ & 2.58 & 0.024 \\
\hline
\end{tabular}

tween growth studies conducted on other Mycteroperca species.

Table 3 shows the results of the growth parameters obtained for males and females and all the specimens by fitting the growth equation of von Bertalanffy to the size-age data estimated by direct 
TABLE 3. - Von Bertalanffy growth parameters for males, females and all fish of Mycteroperca fusca off the Canary Islands.

\begin{tabular}{lccccc}
\hline & $\mathrm{L}_{\infty}(\mathrm{mm})$ & $\mathrm{k}\left(\right.$ years $\left.^{-1}\right)$ & $\mathrm{t}_{0}($ years $)$ & $\mathrm{n}$ & $\mathrm{r}^{2}$ \\
\hline Males & 952 & 0.053 & -5.11 & 35 & 0.915 \\
Females & 888 & 0.063 & -3.73 & 153 & 0.977 \\
Total & 898 & 0.062 & -3.83 & 188 & 0.976 \\
\hline
\end{tabular}

reading of the otoliths. The growth curves for males and females show significant differences $\left(T^{2}\right.$ Hotelling-test, $T^{2}=12.43>T_{0}^{2} 0.05,3,184=7.86$ ).

\section{DISCUSSION}

The estimation of age in serranids is often complicated due to the narrow fit between the growth rings towards the edge of the otolith, especially in older specimens (Harris and Collins, 2000; Manickchand-Heileman and Phillip, 2000). On occasions, the estimation of age is made more difficult due to the thickness of the otoliths, making it necessary to carry out sections of the otoliths. In the case of the island grouper, the narrowness of the otoliths allows us to carry out a correct reading of age without the need for sectioning. The values of the index of average percentage of error and of the coefficient variant suggest that the levels of precision obtained are in line with the reference values as indicated by Campana (2001).

Each year, an opaque ring and a translucent ring are formed, allowing the age to be defined with relative ease. The formation of a sole translucent and opaque ring per year has been detected across all the studies carried out on species of this genus (Collins et al., 1987, 1996; Hood and Schlieder, 1992; Harris and Collins, 2000).

The translucent and opaque rings are each totally deposited on the otoliths of the grouper in winter and summer months, respectively. The opaque ring is totally formed when the temperature of the water reaches its highest levels $\left(24-26^{\circ} \mathrm{C}\right)$, whereas the translucent ring is totally formed when the temperature of the water is lower $\left(18^{\circ} \mathrm{C}\right)$. Manickchand-Heileman and Phillip (2000) and Díaz-Uribe et al. (2001) indicate that a seasonal difference of $2-6^{\circ} \mathrm{C}$ is sufficient to cause the formation of these growth rings. This pattern of opaque ring formation is characterised by being broad-ranging in time and taking place in the summer months, coincident with the pattern described by Matheson et al. (1986) for Mycteroperca phenax, Hood and Schlieder (1992) and Harris and Collins (2000) for Mycteroperca microlepis, Bullock and Murphy (1994) and Díaz-Uribe et al. (2001) for Mycteroperca rosacea, and Manickchand-Heileman and Phillip (2000) for Mycteroperca intertitialis. The data available suggest that the increase in water temperature causes the formation of the opaque ring. The same close link between water temperature and the forming of opaque rings has been found for other species of the same genus, such as $M$. rosacea (Díaz-Uribe et al., 2001). Moreover, Beckman and Wilson (1995) found that for most species distributed over lower latitudes, the period of formation of opaque rings essentially coincided basically with the summer months. Although these cycles of growth in the Serranids may be related to physiological changes linked to temperature, food regimen and the reproductive cycle (Moe, 1969), in this study, the formation of the opaque ring during the period immediately subsequent to the reproduction (February-May) of the species (Bustos, 2008)—coinciding with what occurs in other species of the genus, such as M. phenax (Matheson et al., 1986), M. microlepis (Hood and Schlieder, 1992), Mycteroperca bonaci (Crabtree and Bullock, 1998) and M. interstitialis (Manickchand-Heileman and Phillip, 2000)—would suggest that the formation of rings is associated in these species with changes in the environment rather than being linked to the reproduction process. However, on some occasions the determination of the opaque ring was very difficult because little variation was observed in the environmental conditions (Matheson et al., 1986; Hood and Schlieder, 1992)

The oldest fish found in this study was 20 years old. The maximum age observed was very similar to that found by Matheson et al. (1986) and Manooch (1987) for Mycteropera phenax along the waters of the Atlantic coastline of the USA, where specimens of up to 21 or 17 years were found, respectively. It also coincides with the findings described by Collins et al. (1987) and Díaz-Uribe et al. (2001) for $M$. microlepis and M. Rosacea, in which specimens of 22 years of age and slightly more were registered, and with the findings described by Manooch (1987) in the case of $M$. bonaci (14 years), M. microlepis (16 years) and $M$. venenosa (15 years), in the waters of Florida. However, the maximum age observed differs substantially from that found for Mycteroperca olfax (7 years) in the waters of the Galapagos Islands (Rodríguez, 1984), M. bonaci (33 years) in the waters of Florida (Crabtree and Bullock, 1998), 
M. microlepis (28 years) in the waters of Southern USA (Harris and Collins, 2000), M. rubra (30 years old) in waters off Brasil (Paiva et al., 2004) and $M$. interstitialis (28 and 41 years old) in the waters of the Gulf of Mexico (Bullock and Murphy, 1994) and Trinidad and Tobago (Manickchand-Heileman and Phillip, 2000). The differences found in these areas between the same species or species of the same genus, especially in the island populations, may be attributed to differences in environmental conditions (upwelling), to differences in the reading method used (whole or sectioned otoliths), or to differences in levels of exploitation. Related to this, the populations under high levels of exploitation show changes in growth and in the reproductive pattern (Gulland, 1983), as well as the depletion of the oldest age classes, causing an underestimation of the longevity. In general, the species of the genus Mycteroperca are characteristically long-lived and show slow growth (Hood and Schlieder, 1992; ManickchandHeileman and Phillip, 2000; Diaz-Uribe et al., 2001; Paiva et al., 2004). Age 0 to age 1 specimens were largely unavailable in our sampling effort owing to minimum size limits applied to the fishery. The very low number of individuals of age higher than ten years old in the sample population probably results from their removal from the population through both fishing and natural mortality.

The three models of growth explain over $97 \%$ of the growth pattern, as shown by the determination coefficients for each curve. The use of the von Bertalanffy model has been criticised on various accounts (Booth, 1997), such as the use of parameters of scarce biological significance (Schnute, 1981), or the absence of parameters which bear in mind seasonal variations in the growth rate (Pauly, 1980; Moreau, 1987). Nevertheless, von Bertalanffy's model was chosen for a more exhaustive study of the growth of the grouper, since it affords a simple model with a smaller number of parameters than other models, but allows comparison between species and groups of species.

The island grouper is a slow-growing species, especially as compared with its relative species, Mycteroperca bonaci (0.16 years ${ }^{-1}$, Manooch, 1987), M. olfax (0.181 years ${ }^{-1}$, Rodríguez, 1984), M. microlepis (0.12-0.16 years ${ }^{-1}$, Manooch and Haimovici, 1978; Manooch, 1987; Hood and Schlieder, 1992), M. phenax (0.091 years ${ }^{-1}$, Manooch, 1987; Matheson et al., 1986), M. tigris (0.11 years ${ }^{-1}$; García-Arteaga et al., 1999), M. rubra (0.106 years ${ }^{-1}$, Paiva et al.,
2004) and M. rosacea (0.092 years ${ }^{-1}$, Díaz-Uribe et $a l ., 2001)$. The value of the estimated growth rate in this study is very similar to that given for $M$. interstitialis by Manickchand-Heileman and Phillip (2000) in Trinidad and Tobago (0.057 years $\left.{ }^{-1}\right)$. This low growth pattern, common to all species of the genus Mycteroperca, is characteristic of species with the highest trophic level and a long life cycle (Matheson et al., 1986; Hood and Schlieder, 1992; Bullock and Murphy, 1994; Paiva et al., 2004).

In general, the $t_{0}$ values obtained in this, and all the other studies carried out on this genus, are negative. Related to this, the negative values of $\mathrm{t}_{0}$ are frequent between species with rapid growth in their first phases of life and slow growth later (Craig et al., 1997). The growth among the species of the genus Myteroperca tends to be faster in the first stages of life, slowing down considerably later (Bullock and Murphy, 1994; Manickchand-Heileman and Phillip, 2000; Strelcheck et al., 2003). The growth rate of 0.24-1.24 mm/day during the juvenile phase of M. Microlepis allows it to increase some $80 \mathrm{~mm}$ in size in just 70 days (Strelcheck et al., 2003), and $M$. interstitialis increases by up to $200 \mathrm{~mm} / \mathrm{year}$ in the first few years of life in the waters of Mexico, with a marked later reduction to $25 \mathrm{~mm} /$ year for the ages between 2 and 5 years (Bullock and Murphy, 1994). All this shows that von Bertalanffy's model does not describe the growth of the species of the Mycteroperca genus properly for the first few years of life.

The difference in the growth of males and females is a characteristic of hermaphrodite species (Manickchand-Heileman and Phillip, 2000). Alekseev (1983) indicates that the difference in sizes between males and females of the same age cannot be considered as evidence of the difference in growth rates, since both represent the same specimen in different phases of sexual progression. Bullock and Murphy (1994), however, indicate that the oldest females in each age group are those that reverse to males.

The characteristics of the growth and reproductive aspects (Bustos, 2008) of Mycteroperca fusca make it highly susceptible to overfishing. In order to achieve the right management and recovery of its populations it is necessary to analyse and determine the characteristics of its habitat, and its possible alteration due to anthropic factors, the distribution and the movement of the age groups, and the existence of possible processes of aggregation during the spawning period, as is the case with other species of 
the genus (White et al., 2002; Claro and Lindeman, 2003; Tuz-Sulub et al., 2006). It is also necessary to evaluate how fishing activity affects these aggregation processes, which, in other species, makes them especially vulnerable (Sadovy, 1997).

\section{ACKNOWLEDGEMENTS}

This study was funded by the Government of the Canary Islands. The authors are particularly grateful to two anonymous reviewers for their helpful comments and criticism on the manuscript.

\section{REFERENCES}

Alekseev, F.E. - 1983. Hermaphroditism in porgies (Perciformes, Sparidae). 2. Sexual structured of the populations mechanism of its formation and evolution in scups $P$. orphus, P. ehrenbergi and P. auriga. J. Ichthyol., 23: 61-73.

Beamish, R.J. and D.A. Fournier. - 1981. A method for comparing the precision of a set of age determinations. Can. J. Fish Aquat. Sci., 38: 982-983.

Beckman, D.W. and C.A. Wilson. - 1995. Seasonal timing of opaque zone formation in fish otoliths. In: D.H. Secor, J.M. Dean and S.E. Campana (eds.), Recent developments in fish otoliths research, vol. 19, pp. 27-43. The Bella W Baruch Library in Marine Science, South Caroline.

Bernard, D.R. - 1981. Multivariate analysis as a means of comparing growth in fish. Can. J. Fish. Aquat. Sci., 38: 233-236.

Booth, A.J. - 1997. On the life history of the lesser gurnard (Scorpaeniformes: Triglidae) inhabiting the Agulhas Bank, South Africa. J. Fish. Biol. 51: 1155-1173.

Brulé, T., X. Renán, T. Colás-Marrufo, Y. Hauyon and A.N. TuzSulub. - 2003a. Reproduction in the protogynous black groupe (Mycteroperca bonaci (Poey)) from the southern Gulf of Mexico. Fish. Bull., 101: 463-475.

Brulé, T., C. Deniel, T. Colás-Marrufo and X. Renan. - 2003b. Reproductive biology of gag in the southern Gulf of Mexico. $J$. Fish Biol., 63: 1505-1520.

Bullock, L.H. and M.D. Murphy. - 1994. Aspects of the life history of the yellowmouth grouper, Mycteroperca interstitialis, in the eastern Gulf of Mexico. Bull. Mar. Sci., 55(1): 30-45.

Bustos, R. - 2008. Estudio de los parámetros biológicos del abade Mycteroperca fusca (Lowe, 1836) en aguas del archipiélago canario y situación de sus poblaciones en la isla de El Hierro y la reserva marina de la isla de La Graciosa y de los islotes del norte de Lanzarote. Ph.D. thesis. Univ. Las Palmas de Gran Canaria.

Campana, S.E. - 2001. Accuracy, precision and quality control in age determination, including a review of the use and abuse of age validation methods. J. Fish. Biol., 59: 197-242.

Campana, S.E., M.C. Annand and J.I. McMillan. - 1995. Graphical and statistical methods for determining the consistency of age determinations. Trans. Am. Fish. Soc., 124: 131-138.

Chang, W.B. - 1982. A statistical method for evaluating the reproducibility of age determinations. Can. J. Fish. Aquat. Sci., 39: 1208-1210.

Claro, R. and K.C. Lindeman. - 2003. Spawning aggregation sites of snapper and grouper species (Lutjanidae and Serranidae) on the insular shelf of Cuba. Gulf Caribb. Res., 14: 91-106.

Collins, M.R., C.W. Waltz, W.A. Roumillat and D.L. Stubbs. - 1987. Contribution to the life history and reproductive biology of gag, Mycteroperca microlepis (Serranidae), in the South Atlantic Bight. Fish. Bull., 85: 648-653.

Collins, M.R., S.B. Van Sant and G.R. Sedberry. - 1996. Age validation, movements and growth rates of tagged gag (Myctero- perca microlepis), black sea bass (Centropristis striata) and red porgy (Pagrus pagrus). Biology, fisheries and culture of tropical groupers and snappers. ICLARM Conf. Proc., 48: 158-162.

Crabtree, R.E. and L.H. Bullock. - 1998. Age, growth and reproduction of black grouper, Mycteroperca bonaci, in Florida waters. Fish. Bull. 95: 735-753.

Craig, P., J. Choat, L. Maxe and S. Saucerman. - 1997. Population biology and harvest of the coral reef surgeonfish Acanthurus lineatus in American Samoa. Fish. Bull., 95: 680-693.

Díaz-Uribe, G., J.F. Elorduy-Garay and M.T. González-Valdovinos. -2001. Age and Growth of the Leopard Grouper, Mycteroperca rosacea in the Southern Gulf of California, México. Pacif. Sci., 55(2): 171-182.

García Arteaga, J.P., L.M. Sierra and R. Claro. - 1999. Biology of the tiger grouper, Mycteroperca tigris (Pisces: Serranidae) in the SW Cuban Shelf. II. Feeding, age and growth. Rev. Invest. Mar., 20: 15-21.

Gordoa, A. and B. Molí. - 1997. Age and growth of the sparids Diplodus vulgaris, D. sargus and D. annularis in adult populations and the differences in their juvenile growth patterns in the north-west Mediterranean Sea. Fish. Res., 33: 123-129.

Gulland, J.A. - 1983. Fish stock assessment. A manual of basic methods, vol.1. FAO/Wiley series on Food and Agriculture, Rome.

Harris, P.J. and M.R. Collins. - 2000. Age, growth and age at maturity of gag, Mycteroperca microlepis, from the southeastern United States during 1994-1995. Bull. Mar. Sci., 68: 105-117.

Heemstra, P.C. - 1991. A taxonomic revision of the eastern Atlantic groupers (Pisces: Serranidae). Bol. Mus. Mun. Funch., 43 (226): $5-71$

Heemstra, P.C. and J.E. Randall. - 1993. FAO species catalogue, vol. 16: Groupers of the world (Family Serranidae, Subfamily Epinephelinae). An annotated and illustrated catalogue of the grouper, rockcod, hind, coral grouper and lyretail species known to date. FAO Fish. Synop., 125: 1-382.

Heemstra, P.C. and J.E. Randall. - 1999. Serranidae. In: K.E. Carpenter and V.H. Niem (eds.), FAO Species Identification guide for fishery purposes, pp. 2442-2547. FAO, Rome.

Hood, P.B. and R.C. Schlieder. - 1992. Age, growth and reproduction of gag, Mycteroperca microlepis, in the eastern Gulf of Mexico. Bull. Mar. Sci., 51(3): 337-352.

Jennings, S., M.J. Kaiser and J.D. Reynolds. - 2001. Marine fisheries ecology. Blackwell Science, London.

Manickchand-Heileman, S.C. and D.A.T. Phillip. - 2000. Age and growth of the yellowedge grouper, Epinephelus flavolimbatus, and the yellowmouth grouper, Mycteroperca interstitialis, off Trinidad and Tobago. Fish. Bull., 98: 290-298.

Manooch, C.S. - 1987. Age and growth of snappers and groupers. In: J.J. Polovina and S. Ralston (eds.), Tropical snappers and groupers: Biology and fisheries management, pp. 329-374. Westview Press, Boulder.

Manooch, C.S. and M. Haimovici. - 1978. Age and growth of the gag, Mycteroperca microlepis, and size-age composition of the recreational catch off the Southeastern United States. Trans. Am. Fish. Soc., 10: 234-240.

Matheson, R.H., G.R. Huntsman and C.S. Manooch. - 1986. Age, growth, mortality, food and reproduction of the scamp, Mycteroperca phenax, collected off North Carolina and South Carolina. Bull. Mar. Sci., 38(2): 300-312.

McCurdy, W.J., J. Panfili, F.J. Meunier, A.J. Geffen and H. de Pontual. - 2002. Preparation of calcified structures. In: J. Panfili, H. de Pontual, H. Troadec and P.J. Wright (eds.), Manual of sclerochonology, pp. 129-134. Ifremer-IRD edition, Brest.

Moe, M.A. - 1969. Biology of the red grouper Epinephelus morio (Valenciennes) from the eastern Gulf of Mexico. Fla. Dep. Nat. Resour. Mar. Res. Lab. Prof. Pap. Ser., 10: 1-95.

Morales-Nin, B. - 1987. Métodos de determinación de la edad en los osteíctios en base a estructuras de crecimiento. Inf. Téc. Inst. Inv. Pesq., 143: 1-30.

Morales-Nin, B. and J. Panfili. - 2002a. Indirect validation. In: J. Panfili, H. de Pontual, H. Troadec and P.J. Wright (eds.), Мапиal of sclerochonology, pp. 135-137. Ifremer-IRD edition, Brest

Morales-Nin, B. and J. Panfili. - 2002b. Age estimation. In: J. Panfili, H. de Pontual, H. Troadec and P.J. Wright (eds.), Manual of sclerochonology, pp. 91-98. Ifremer-IRD edition, Brest.

Moreau, J. - 1987. Mathematical and biological expression of growth in fishes: Recent trends and further developments. In: 
R.C. Summerfelt and G.E. Hall (eds.), Age and growth of fish, pp 81-113. Iowa State University Press, Iowa.

Paiva, M.P., M.O. Ximenes-Carvalho and A.A. Fonteles-Filho. - 2004. Idade e crescimento do badejo-mira, Mycteroperca rubra (Bloch, 1793), no sudeste do Brasil. Arq. Cienc. Mar., 37: 7-14.

Pajuelo, J.G. and J.M. Lorenzo. - 1995. Análisis y predicción de la pesquería demersal de las Islas Canarias mediante un modelo ARIMA. Sci. Mar. 59: 155-164.

Panfili, J. and B. Morales-Nin. - 2002a. Semi-direct validation. In: J. Panfili, H. de Pontual, H. Troadec and P.J. Wright (eds.), Manual of sclerochonology, pp. 129-134. Ifremer-IRD edition, Brest.

Panfili, J. and B. Morales-Nin. - 2002b. Influence of the shape and structure on the interpretation. In: J. Panfili, H. de Pontual, H. Troadec and P.J. Wright (eds.), Manual of sclerochonology, pp. 105-113. Ifremer-IRD edition, Brest.

Pauly, D. - 1980. On the interrelationships between natural mortality, growth parameters, and mean environmental temperature in 175 fish stocks. J. Cons. int. Explor. Mer, 39: 175-195.

Pauly, D., V. Christesen, J. Dalsgaard, R. Froese and F. Torres. 1988. Fishing down marine food webs. Science, 279: 860-863.

Pitcher, T.J. and P.D.M. Macdonald. - 1973. Two models for seasonal growth in fishes. J. Appl. Ecol., 10: 597-606.

Ricker, W.E. - 1975. Computation and interpretation of biological statistics of fish populations. Bull. Fish. Res. Board Can., 191: 1-382.

Rodríguez, W.T. - 1984. Estudio preliminar para evaluar las características biológicas y pesqueras de Mycteroperca olfax en las islas Galápagos (Ecuador). Bol. Cient. Téc., Inst. Nac. Pesca, Guayaquil-Ecuador, 6(3): 3-66.

Sadovy, Y. - 1997. Problems of sustainability in grouper fisheries. In: Y.Q. Zhou, H.Q. Zhou, C.Q. Yao, Y. Lu, F.Y. Hu, H. Cuy and F.H. Din (eds.), Proc.Fourth Asian Fish. Forum, pp. 321-
324. Ocean Press, Beijing.

Sadovy, Y. and D.Y. Shapiro. - 1987. Criteria for the diagnosis of hermaphroditism in fishes. Copeia, 1: 136-156.

Schnute, J. - 1981. A versalite growth model with statistically stable parameters. Can. J. Fish. Aquat. Sci., 38: 1128-1140.

Sokal, R.R. and F.J. Rohlf. - 1995. Biometry: the principles and practice of statistics in biological research. W.H. Freeman, New York.

Strelcheck, A.J., G.R. Fitzhugh, F.C. Coleman and C.C. Koenig. -2003 . Otolith-fish size relationship in juvenile gag (Mycteroperca microlepis) of the eastern Gulf of Mexico: a comparison of growth rates between laboratory and field populations. Fish. Res., 60: 255-265.

Tuya, F., P. Sánchez-Jerez and R.J. Haroun. - 2005. Population of inshore serranids across the Canarian Archipelago: Relationships with human pressure and implications for conservation. Biol. Cons., 12: 13-24.

Tuz-Sulub, A.N., T. Brulé, K. Cervera and J.C. Espinoza-Mendez. -2006. Evidence for sexual dichromatisms aggregations of yellowfin grouper Mycteroperca venenosa and grouper Mycteroperca tiger the southern Gulf of Mexico. J. Fish Biol., 69: 1744-1755.

White, D.B., D.M. Wyansky, B.M. Eleby and C.G. Lilyestrom. -2002. Tiger grouper (Mycteroperca tigris): profile of a spawning aggregation. Bull. Mar. Sci., 70: 233-240.

Wright, P.J., J. Panfili, B. Morales-Nin and A.J. Geffen. - 2002. Otolith. In: J. Panfili, H. de Pontual, H. Troadec and P.J. Wright (eds.), Manual of sclerochonology, pp. 31-57. Ifremer-IRD edition, Brest.

Scient. ed.: I. Palomera.

Received November 19, 2007. Accepted October 3, 2008.

Published online March 4, 2009. 